\section{Analysis of the Epithelium- Mesenchymal Transition Process on Oral Squamous Cell Carcinomas}

Taiane Berguemaier de Lima, Isadora Peres Klein, Márcia Gaiger de Oliveira, Pantelis Varvaki Rados, Manoel Sant'Ana Filho, Fernanda Visioli
Oral Pathology Department, School of Dentistry, UFRGS Universidade Federal do Rio Grande do Sul, Porto Alegre, RS, Brazil

Correspondence: Fernanda Visioli, Rua Ramiro Barcelos 2492, 90035003 Porto Alegre, RS, Brazil. Tel: +55-51-3308-5011. e-mail: fernanda.visioli@ufrgs.br

\begin{abstract}
The aim of this study is to evaluate the immunohistochemical expression of E-cadherin, $\mathrm{N}$-cadherin and $\mathrm{Bmi}-1$, and their association with clinical parameters and with the degree of histopathological differentiation in oral squamous cell carcinomas. 65 squamous cell carcinoma samples were used for constructing a tissue microarray block, and then immunohistochemistry was performed for different markers. A semi-quantitative analysis of the amount of positive tumor cells was performed by two blind and calibrated observers (Kappa $>0.75$ ). The statistical Mann-Whitney and Kruskal-Wallis tests were used to evaluate the data. The correlation between variables was investigated by the Spearman test, and the significance level set at $p<0.05$. We observed higher expression of $\mathrm{Bmi}-1$ in tumors located in the palate $(p<0.0001)$. In addition, poorly differentiated tumors had a greater amount of Bmi-1 positive cells $(p=0.0011)$. Regarding the other correlations between variables, no significant associations were detected. In conclusion, poorly differentiated squamous cell carcinomas located in the palate have higher immunostaining of Bmi-1, which can characterize activation of the Epithelial-Mesenchymal Transition process in these tumors.
\end{abstract}

Key Words: oral cancer, prognosis, E-cadherin, N-cadherin, Bmi-1.

\section{Introduction}

Squamous cell carcinoma represents the most common malignant neoplasm involving the oral cavity, representing around $95 \%$ of all malignancies affecting this location $(1,2)$. Oral squamous cell carcinoma (OSCC) is considered the sixth most common type of cancer worldwide. Despite advances in diagnosis and treatment, OSCC continues to have a low 5 -year survival rate (3).

The aggressiveness of this disease is related to the ability of tumor cells to invade other tissues and originate metastases. This capability is directly related to the phenomenon known as epithelium-mesenchymal transition (4). The epithelium-mesenchymal transition (EMT) is a dynamic and reversible cellular process. During the development of this process there is a transition of an epithelial cell phenotype to cells with mesenchymal characteristics, with increased migratory capacity and, this is due in part to the modulation of cell polarity and of cell adhesion (5). The cells of the epithelial tissue are characterized by cell-cell contact and also by the formation of adherens junctions, a function exerted by molecules such as cadherins, which are a family of transmembrane glycoproteins.

Among the cadherin sub-types it is important to highlight the E-cadherin and the $\mathrm{N}$-cadherin, their difference being the place of activity of each molecule. The E-cadherin (E-CAD) is expressed in most epithelial cells, having an important role in establishing cell polarity, in the adhesion between epithelial cells and in the maintenance of tissue architecture (6). This molecule is composed of a cytoplasmic domain that binds to the cytoskeletal through heterotypic interactions with proteins called catenins. This establishes the cytoplasmic complex of cellular adhesion, important for the formation of cell-cell extracellular adhesion (7). Also, they play a signaling role in cell growth and differentiation $(5,8)$. In contrast, the $\mathrm{N}$-cadherin (N-CAD) is mostly found in neural and mesenchymal cells (9). EMT is characterized by the loss of E-cadherin and gain of $\mathrm{N}$-cadherin expressions (10). In this process the cancer cells gain greater migratory ability and thus the ability to escape from the primary focus, colonizing distant sites and forming metastases.

The epithelial-mesenchymal transition is modulated by a number of transcription factors, including Bmi-1, which is a constituent of the Polycomb group (PCG) and has a role in regulating the cell cycle, embryogenesis and lymphopoiesis (11). The genes that form the Polycomb group have the function of silencing genes, regulating the chromatin structure and operating in the self-renewal of normal and neoplastic cells (12). This transcription factor activates the EMT, increasing the mobility and the invasion of malignant cells. The Bmi-1 expression increases in tumor tissues compared to adjacent tissues, and it is associated 
with more aggressive clinical characteristics, such as: tumor size, metastases and clinical stage of the tumor (13). Bmi1 is also involved in the regulation of gene expression of tumor stem cells, maintaining their indifferentiation and capacity of cellular self-renewal $(5,14)$.

The purpose of this study was to evaluate the immunohistochemical expression of $\mathrm{E}$-cadherin, $\mathrm{N}$-cadherin and Bmi-1, and their association with clinical parameters (site of injury, sex and age of the patient) and with the degree of histopathological differentiation in oral squamous cell carcinomas.

\section{Material and Methods}

\section{Samples and TMA Preparation}

This study was approved by the Ethical Committee from the institution where samples were collected. Informed consent was obtained from all patients prior to sample collection. Human primary oral squamous cell carcinomas $(n=65)$ were selected after the slides were reviewed by a pathologist. Samples were formalin fixed and paraffin embedded. In order to choose representative fields, the hematoxylin and eosin-stained slides from each specimen were analyzed. Two tissue cylinders of 1-mm in diameter, recipient block contained 130 OSCC cores and 12 human samples used as positive control cores (placenta tissues, tonsil, breast cancer, and lung cancer).

\section{Immunohistochemistry}

Four-micrometer-thick sections were deparaffinized and rehydrated through ethanol. After antigen heat retrieval was performed on microwave, the sections were incubated with primary antibodies for N-CAD (clone $a b$, dilution 1:200, Abcam, Cambridge, UK), Bmi-1 (clone ab38295, dilution 1:100, Abcam) and E-CAD (clone 3195, dilution 1:400, Cell Signalling, Danvers, MA, USA) for 1 hour at room temperature. The secondary antibody system used was EnVisionTM+ Dual Link system (Dako, Carpinteria, CA, USA); and 3,3-diamino benzidine (Dako) was used for visualization. For each core, 400x magnification images were captured using a video camera (0-Color5TM, Olympus America, Inc., Center Valley, PA, USA) coupled to a microscope.

The cores were scored according to percentage of the total number of cells and graded semiquantitatively (Fig. 1). For E-CAD analysis, the following scores were used: $0 \%=0$ positive cells, $01-10 \%$ positive cells $=1,11-75 \%$ positive cells $=2,>75 \%$ positive cells $=3(15)$. For N-CAD quantification, the following scores were used: < 1\% positive cells $=0,01-40 \%$ positive cells $=1,40-80 \%$ positive cells $=2,>80 \%$ positive cells $=3$ (16). For Bmi-1, the same score system used for $\mathrm{N}$-cadherin was applied. Slides were assessed by previously calibrated two oral pathologists with acceptable intra-observer and interobserver kappa values $(0.7-1.0)$.

\section{Statistical Analysis}

The Mann-Whitney or the Kruskal-Wallis nonparametric tests, followed by the Dunn's multiple comparison test, were used to compare the staining scores according to the studied variables. Spearman's correlation coefficient was used to assess correlations between variables. Significance was set at $p<0.05$.

\section{Results}

The study analyzed 65 cases of oral squamous cell carcinoma. Table 1 shows the demographic data of the sample. A higher number of cases were observed in male patients (86.15\%), in the age group of 51-60 years (35.4\%), and the most frequent location was the gingiva (32.31\%).

When comparing the expression of markers with the location of the tumor, the study found that tumors in the palate have a higher score for Bmi-1. However, E-CAD and $\mathrm{N}-\mathrm{CAD}$ markers showed a similar marking in all locations of tumors (Table 2). The different markers were evaluated according to the age and sex variables and these did not affect the immunohistochemical staining of the three markers (Table 2).

The distribution of positive cells for the different markers was also evaluated according to the histopathological grading of the tumor (Fig. 2). The Bmi-1 marker showed a statistically significant difference, with the highest number of positive cells in the poorly differentiated tumors. The correlation between markers was analyzed and an inverse correlation between Bmi-1 and E-CAD, and between E-CAD and N-CAD was observed; as well as a positive correlation between N-CAD and Bmi-1; however, these correlations were not statistically significant (Table 3 ).

\section{Discussion}

The aim of this study was to correlate the immunohistochemical expression of molecules E-cadherin, $\mathrm{N}$-cadherin and Bmi-1, important markers of the EMT process, and consequently of tumor behavior, with the degree of histological differentiation in oral squamous cell carcinomas and their association with clinical parameters (site of injury, sex and age of patient).

Regarding the anatomical site, we found that the Bmi1 marker expression was higher in lesions located on the palate. The literature reports that Bmi-1 is a transcription factor associated with increased aggressiveness and 
consequently of decreased patient survival rates (17). The overexpression of Bmi-1 was observed to be associated with the induction of EMT, thus promoting the migration, invasion and worse prognosis of tumors (18). Furthermore, as the Bmi-1 marker increases, a decrease of the $\mathrm{E}$-cadherin marker and increase of the $\mathrm{N}$-cadherin marker were observed in neoplastic cells through the correlation analyses. Thus, it may be inferred that Bmi-1 acts to increase motility and the ability to invade the other tissues through

Table 1. Demographic and clinical-pathological characteristics of the sample

\begin{tabular}{|c|c|c|}
\hline Characteristics & $\mathrm{N}$ & $\%$ \\
\hline \multicolumn{3}{|l|}{ Sex } \\
\hline Male & 56 & 86.15 \\
\hline Female & 09 & 13.85 \\
\hline \multicolumn{3}{|l|}{ Age (years) } \\
\hline $40-50$ & 16 & 24.6 \\
\hline $51-60$ & 23 & 35.4 \\
\hline $61-90$ & 21 & 32.3 \\
\hline NI & 05 & 7.7 \\
\hline \multicolumn{3}{|l|}{ Tumor location } \\
\hline Palate & 05 & 7.7 \\
\hline Lower Lip & 06 & 9.23 \\
\hline Tongue & 13 & 20.00 \\
\hline Floor of mouth & 20 & 30.77 \\
\hline Gingiva & 21 & 32.31 \\
\hline \multicolumn{3}{|l|}{ Histopathological grading } \\
\hline Well differentiated & 26 & 40 \\
\hline Moderately differentiated & 27 & 41.53 \\
\hline Poorly differentiated & 12 & 18.47 \\
\hline
\end{tabular}

the increased expression of $\mathrm{N}$-cadherin and decrease expression of E-cadherin.

The tumors with the highest staining for Bmi-1, the palate lesions, may be more likely to cause metastasis in comparison with other lesions. The literature reported a $40 \%$ rate of regional metastases of palate OSCC at the time of the diagnosis (19). Moreover, a study about the main factors related to oropharyngeal carcinoma (base of tongue, uvula, tonsils and palate) found that most injuries on the palate progress to stage III and IV of the TNM system, suggesting high aggressiveness of these tumors (20).

In this sample no relation was detected between the location of the palate and the histopathological grading; the palate lesions showed different degrees without predominance of anyone. However, a correlation was detected between the Bmi-1 expression and the histopathological grading in the studied samples - the higher the Bmi-1 expression, the lower the degree of histopathological differentiation of the OSCC. The

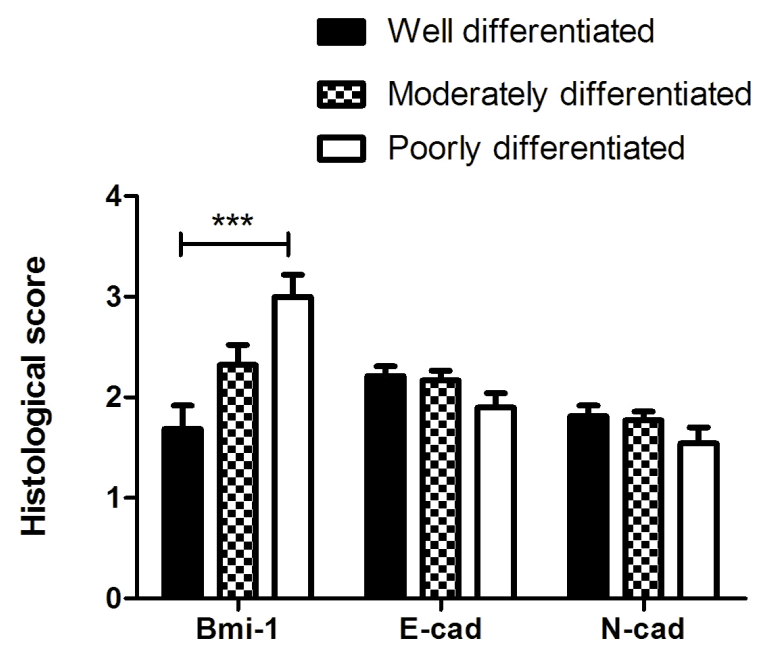

Figure 2. Immunomarkers scoring according to the histopathological grading of the tumors. ${ }^{* * *} \mathrm{p}<0.001$, Kruskal-wallis and Dunn's posthoc test.
E-CAD

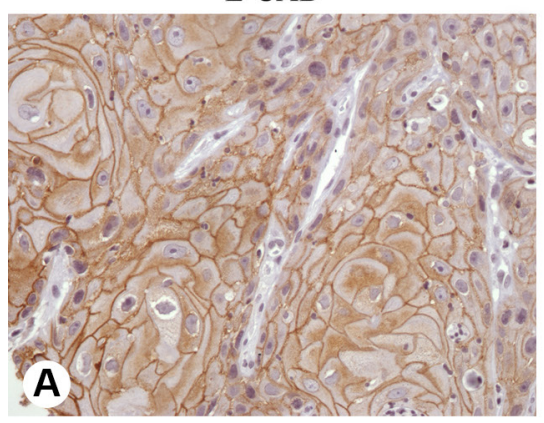

N-CAD

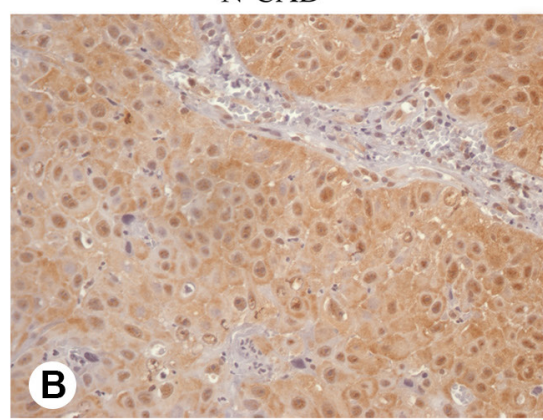

BMI-1

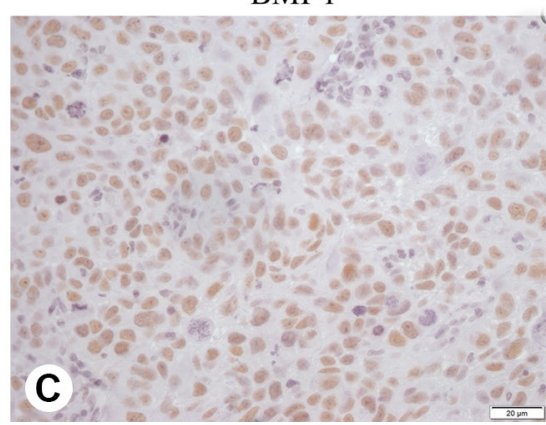

Figure 1. Immunohistochemical markers E-CAD, N-CAD and BMI-1 in oral squamous cell carcinomas. A) E-cadherin expression in a well differentiated tumor. B) $\mathrm{N}$-cadherin expression in a moderately differentiated tumor. C) Bmi-1 expression in a poorly differentiated tumor. 
degree of histological differentiation is directly related to patient prognosis, i.e., the lower the degree of histological differentiation the more aggressive the tumor is (21). The literature reports that $\mathrm{Bmi}-1$ expression in bladder tumors, wherein the higher expression of Bmi-1 protein also provided a lower degree of differentiation, increased risk of recurrence and worse prognosis, confirming our results in relation to Bmi-1 expression in poorly differentiated tumors (22). Thus, the Bmi-1 expression is considered a prognostic marker for neoplasias, since the high expression of Bmi-1 is associated with increased tumor invasiveness and the development of metastasis, resulting in more aggressive behavior of tumor cells $(12,18)$.

An inverse correlation between E-cadherin and $\mathrm{N}$-cadherin was found in this study, although it was not

Table 2. Correlation between immunomarkers and sex, age and the anatomical site of the lesions

\begin{tabular}{|c|c|c|c|c|c|c|}
\hline & \multicolumn{2}{|c|}{ BMI-1 } & \multicolumn{2}{|c|}{ E-CAD } & \multicolumn{2}{|c|}{$\mathrm{N}-\mathrm{CAD}$} \\
\hline & Median & (Q1-Q3) & Median & (Q1-Q3) & Median & (Q1-Q3) \\
\hline \multicolumn{7}{|l|}{ Sex } \\
\hline Male & 2 & $(0-3)$ & 2 & $(2-3)$ & 2 & $(1-3)$ \\
\hline Female & 2 & $(0.25-3.5)$ & 2 & $(2-3)$ & 2 & $(1.75-3)$ \\
\hline$p^{*}$ & 0.8032 & & 0,9342 & & 0.1156 & \\
\hline \multicolumn{7}{|l|}{ Age } \\
\hline $41-50$ & 2 & $(0.75-3)$ & 3 & $(2-3)$ & 1 & $(0-2)$ \\
\hline $51-60$ & 2 & $(0.5-3.5)$ & 2 & $(2-3)$ & 2 & $(1-2)$ \\
\hline $61-90$ & 2 & $(0-4)$ & 2 & $(2-3)$ & 2 & $(1.75-2)$ \\
\hline$p^{* * *}$ & 0.8468 & & 0.4139 & & 0.1575 & \\
\hline \multicolumn{7}{|l|}{ Location } \\
\hline Floor of mouth & $3 a$ & $(2-4)$ & 2 & $(2-3)$ & 2 & $(1-2)$ \\
\hline Gingiva & $2 \mathrm{a}$ & $\begin{array}{c}(0.75- \\
2.25)\end{array}$ & 2 & $(2-3)$ & 2 & $(1-2)$ \\
\hline Lower Lip & $2 \mathrm{a}$ & $(0-3)$ & 2 & $(1-2)$ & 2 & $(1-2)$ \\
\hline Tongue & $3 a$ & $(0,5-4)$ & 2 & $(1-2)$ & 2 & $(1-2)$ \\
\hline Palate & $4 b$ & $(4-4)$ & 2,5 & $(2-3)$ & 2 & $(1-2,5)$ \\
\hline$p^{* *}$ & $<0.0001$ & & 0.0585 & & 0.9804 & \\
\hline
\end{tabular}

$p^{*}$, Mann-Whitney $\cdot p^{* * *}$, Kruskal-Wallis and Dunn's post-hoc test. significant. The literature shows greater reduction of E-cadherin expression when there is higher $\mathrm{N}$-cadherin expression (9). The $\mathrm{N}$-cadherin molecule is related to the processes of invasion and metastasis (23). Corroborating these findings, this study found a positive correlation between $\mathrm{N}$-cadherin and Bmi-1 that is related to the induction of these processes, although it is not a significant correlation. Thus the imbalance of molecules E-cadherin and $\mathrm{N}$-cadherin must be considered an important indicator of prognosis and a potential therapeutic target for patients with OSCC (16).

In this sample of patients with oral squamous cell carcinoma most were men aged 50 to 60 years old. This demographic data is consistent with data from other previously published epidemiological studies $(2,4)$. Overall, it is believed that the prevalent habit of smoking associated or not with alcoholism is more frequent in males, which results in greater male prevalence (1). Furthermore, this study has found that squamous cell carcinoma lesions were present in various anatomical sites of the oral cavity; however, these injuries were predominant in the gingiva region. Following gingiva, lesions were more common on the floor of mouth and tongue, and in this respect our sample is consistent with other studies in the literature $(24,25)$.

According to the results obtained in this study, it possible to conclude that increased Bmi-1 expression results in a trend of increased expression of $\mathrm{N}$-cadherin, characterizing the process of EMT; and also that the

Table 3. Correlation between immunomarkers and the histopathological grading of the tumor.

\begin{tabular}{lccc}
\hline & BMI-1 & E-CAD & N-CAD \\
\hline BMI-1 & ------ & $-0.0822(p=0.3761)$ & $0.0509(p=0.6132)$ \\
E-CAD & $-0.0822(p=0.3761)$ & $-0.1315(p=0.1611)$ \\
N-CAD & $0.0509(p=0.6132)$ & $-0.1315(p=0.1611)$ & $-0.3278(p=0.0011)$ \\
\hline
\end{tabular}

$p$, Spearman coefficient. 
activation of this process results in a histopathological grading of greater cell differentiation and therefore greater tumor aggressiveness.

\section{Resumo}

0 objetivo deste estudo foi avaliar a associação entre a expressão imunoistoquímica de $\mathrm{E}$-caderina, $\mathrm{N}$-caderina e $\mathrm{Bmi}-1$, com os parâmetros clínicos e o grau de diferenciação em carcinomas espinocelulares bucais. Sessenta e cinco amostras foram selecionadas para a construção de um bloco de microarranjo tecidual, e a técnica de imunoistoquímica foi realizada para os diferentes marcadores. Uma análise semi-quantitativa das células tumorais positivas foi realizada por dois observadores calibrados e cegos (Kappa $>0.75$ ). Os testes estatísticos Mann-Whitney e Kruskal-Wallis foram utilizados para a análise dos dados e a correlação entre as variáveis foi investigada com o teste de Spearman. 0 nivel de significância foi determinado em $p<0.05$. Observamos maior expressão de Bmi-1 em tumores localizados em palato ( $p<0.0001)$. Além disso, tumores pobremente diferenciados apresentaram maior quantidade de células positivas para Bmi-1 $(p=0.0011)$. Não encontramos outras correlações ou associações significativas. Em conclusão, carcinomas espinocelulares pobremente diferenciados e localizados no palato apresentam maior marcação imunoistoquímica de Bmi-1, o que pode caracterizar a ativação do processo de transição epitélio-mesênquima nesses tumores.

\section{Acknowledgements}

We would like to thank Isabel da Silva Lauxen for technical and intellectual support and also the National Council for Scientific and Technological Development (CNPO) for financial support.

\section{References}

1. Johnson NW, Jayasekara P, Amarasinghe AA. Squamous cell carcinoma and precursor lesion of the oral cavity: epidemiology and aetiology. Periodontol 2000 2011;57;19-37.

2. Dragomir LP, Simionescu C, DaGuci L, Searpe M, Dragomir M. Clinical, Epidemiological And Histopathological Prognostic Factors In Oral Squamous Carcinoma. Cur Health Sci J 2010; 36:201-205.

3. Scully C, Bagan J. Oral squamous cell carcinoma: overview of current understanding of a etiopathogenesis and clinical implications. Oral Dis 2009;15:388-399.

4. El-Naggar AK, Chan JKC, Grandis JR, Takata T, Slootweg PJ. World Health Organization Classification of Tumours: Pathology and Genetics of Head and Neck Tumours. 4th ed. Lyon: IARCPress; 2017.

5. Smith A, Teknos NT, Pan 0. Epithelial to mesenchymal transition in head and neck squamous cell carcinoma. Oral Oncol 2013;49:287-292.

6. Liu LK, Jiang XY, Zhou XX, Wang DM, Song XL, Jiang HB. Upregulation of vimentin and aberrant expression of E-cadherin/beta-catenin complex in oral squamous cell carcinomas: correlation with the clinicopathological features and patient outcome. Mod Pathol 2010;23:213-224.

7. Beavon IRG. The E-cadherin-catenin complex in tumour metastasis: structure, function and regulation. Eur J Cancer 2000;36:1607-1620.

8. Rajwar YC, Jain N, Bahtia G, Sikka N, Garg B, Walia B. Expression and Significance of Cadherins and Its Subtypes in Development and
Progression of Oral Cancers: A Review. J Clin Diag Res 2015;9:ZE05-07.

9. Pyo WS, Hashimoto M, Kim SY, Kim HC, Lee HS, Johnson RK, et al. Expression of $\mathrm{E}$-cadherin, $\mathrm{P}$-cadherin and $\mathrm{N}$-cadherin in oral squamous cell carcinoma: Correlation with the clinicopathologic features and patient outcome. J Craniomaxillofac Surg 2007;35:1-9.

10. Nguyen PT, Kudo Y, Yoshida M, lizuka S, Ogawa I, Takata T. N-cadherin expression is correlated with metastasis of spindle cell carcinoma of head and neck region. J Oral Pathol Med 2011;40:77-82.

11. Raaphorst MF. Self-renewal of hematopoietic and leukemic stem cells: a central role for the Polycomb-group gene Bmi-1. Trends In Immunol 2003;24:522-524.

12. Bhattacharya $R$, Mustafi BS, Street $M$, Dey A, Dwivedi DKS. Bmi-1: At the crossroads of physiological and pathological biology. Genes Dis 2015;2:225-239.

13. Guo $B$, Feng $Y$, Zhang $R$, $X u L$, Li M, Kung $H$, et al. Bmi-1 promotes invasion and metastasis, and its elevated expression is correlated with an advanced stage of breast cancer. Mol Cancer 2011;10:10.

14. Li H, Song F, Chen $X, L i Y$, Fan J, Wu X. Bmi-1 regulates epithelial-tomesenchymal transition to promote migration and invasion of breast cancer cells. Int J Clin Exp Pathol 2014;7:3057-3064.

15. Mostaan LV, Khorsandi MT, Sharifian SM, Shandiz FH, Mirashrafi F, Sabzari $\mathrm{H}$, et al. Correlation between E-cadherin and CD44 adhesion molecules expression and cervical lymph node metastasis in oral tongue SCC: Predictive significance or not. Pathol Res Pract 2011;207:448-451.

16. Zhao D, Tang $X$, Yang K, Liu J, Ma X. Over-expression of integrin-linked kinase correlates with aberrant expression of Snail, E-cadherin and $\mathrm{N}$-cadherin in oral squamous cell carcinoma: implications in tumor progression and metastasis. Clin Exp Metastasis 2012;29:957-969.

17. Giudice SF, Pinto JRSD, Nör JE, Squarize HC, Castilho MR. Inhibition of Histone Deacetylase Impacts Cancer Stem Cells and Induces Epithelial-Mesenchyme Transition of Head and Neck Cancer. Plos One 2013;8:e58672.

18. Chang B, Li S, He Q, Liu Z, Zhao L, Zhao T, et al. Deregulation of Bmi-1 is associated with enhanced migration, invasion and poor prognosis in salivary adenoid cystic carcinoma. Biochim Biophys Acta 2014;1840:3285-3291.

19. Li $\mathrm{Q}$, Wu D, Liu WW, Li H, Liao WG, Zhang XR, et al. Survival impact of cervical metastasis in squamous cell carcinoma of hard palate. Oral Surg, Oral Med, Oral Pathol Oral Radiol 2013;116:23-27.

20. Sundaram K, Schwartz J, Har-El G, Lucente F. Carcinoma of the Oropharynx: Factors Affecting Outcome. Laryngoscope 2005;115: 1536-1542.

21. Garzino-Demo $P$, Zavattero $E$, Franco $P$, Fasolis $M$, Tanteri G, Mettus $A$ et al. Parameters and outcomes in 525 patients operated on for oral squamous cell carcinoma. J Craniomaxillofac Surg 2016;44:1414-1421.

22. Qin $K Z$, Yang J, Ye $Y$, Zhang $X, X u L H$, Zhou FJ, Han $H$, et al. Expression of Bmi-1 is a prognostic marker in bladder cancer. BMC Cancer 2009;9:61.

23. Hazan BR, Phillips RG, Qiao FR, Norton L, Aaronson AS. Exogenous Expression of $\mathrm{N}$-Cadherin in Breast Cancer Cells Induces Cell Migration, Invasion, and Metastasis. J Cell Biol 2000;148:779-790.

24. Montoro JR, Ricz AH, Souza L, Livingstone $D$, Melo $H D$, Tiveron $C R$, et al. Prognostic factors in squamous cell carcinoma of the oral cavity. Braz J Otorhinolaryngol 2008;74:861-866.

25. Qaisi M, Vorrasi J, Lubek J, Ord R. Multiple Primary Squamous Cell Carcinomas of the Oral Cavity. J Oral Maxillofac Surg 2014;72;15111516. 